\title{
UČESTALOST ANAEROBNE MOĆI KOD BRAZILACA NA OSNOVU DERMATOGLIFIKE I R577X POLIMORFIZMA ACTN3 PROTEINA
}

\author{
Carlos Renato Paz ${ }^{1,3,6}$, Ramon Cunha Montenegro ${ }^{1,2,3}$, Eric de Lucena Barbosa ${ }^{1,2,6}$, \\ Asdrúbal Nóbrega Montenegro-Neto ${ }^{2}$, Sérgio Marques de Lucena ${ }^{4}$, \\ Vanduir Soares de Araújo Filho ${ }^{2,4,6}$, Paula Roquetti Fernandes ${ }^{5,6}$ i José Fernandes Filho ${ }^{1,5,6}$ \\ ${ }^{1}$ Autonomni univerzitet Asuncion, Asuncion, Paragvaj \\ ${ }^{2}$ Labratorija za procjenu fizičkih sposobnosti` UNIPÊ - SANNY, João Pessoa, Paraíba, \\ Brazil \\ ${ }^{3}$ Savezni institut za obrazovanje, nauku i tehnoligiju u Paraibu - IFPB, João Pessoa, \\ Paraíba, Brazil \\ ${ }^{4}$ Policijski naučni institut u Paraibu SPI-OB, João Pessoa, Paraíba, Brazil \\ ${ }^{5}$ Centar za procjenu vrhunskih fizičkih kvaliteta, Rio de Žaneiro, Brazil \\ ${ }^{6} \mathrm{LABIMH-UFRJ} \mathrm{-} \mathrm{Istraživačka} \mathrm{grupa,} \mathrm{Rio} \mathrm{de} \mathrm{Žaneiro,} \mathrm{Brazil}$
}

\section{SAŽETAK}

Dermatoglifika i analize Alfa-aktin gena su evluativni instrumenti koji se često koriste za selekciju sportista i uopšte populacije u odnosu na motoričke vještine. Ovo istraživanje imalo je za cilj da utvrdi, na osnovu dermatoglifskih karakteristika i R577X polimorfizma Alfa-aktina, procenat ljudi u saveznoj brazilskoj državi Paraiba sa nepovoljnim sposobnostima za sportove koje karakterišu anaerobne sposobnosti. Izvršena je deskriptivna studija profila sa eks post fakto tipologijom. Identifikovani su dermatoglifski otisci prstiju 309 osoba (149 muškaraca i 160 žena), a ACTN3 genotip je analiziran na njih 96 (40 muškaraca i 56 žena). Dermatoglifski podaci pokazuju da 5,8\% populacije obuhvaćene istraživanjem odgovara anaerobnim predispozicijima mišićne moći, dok $94,2 \%$ nema te sposobnosti. Genetička analiza frekvencija ukazala je na činjenicu da su 19,8\% ispitanika imali XX mutan genotip. Ovi rezultati predstavljaju značajano smanjenje greške u izboru sportista za potencijalno vrhunske rezultate pogotovu u onim sportovima koji zahtijevaju AMP..

Ključne riječi: Alfa-aktin, otisci prstiju, genetski polimorfizam, skeletni mišić, frekvencija genotipa.

\section{UVOD}

Potraga za sportskim talentim je fenomen koji neprestano raste i sa sobom donosi i dragocjena potencijalna ulaganja u vrhunski sport. Shodno tome, korišćenje adekvatnih specifičnih instrumenata je osnova za identifikovanje perspektivnih sportista. Ti instrumenti pomažu da se smanji mogućnost greške i preveliki finansijski rashodi tako što se povećava broj sportista koji mogu da dosegnu visoke sposobnosti u različitim sportovima (Kansal, 2010).

Jedna od metoda koja se koristi za procjenu sportista koji posjeduju visoke sposobnosti je dermatoglifika, pristup koji obuhvata analizu uzoraka kožnih papila koji vode porijeklo iz neurovaskularnih regija.
Ti regioni se formiraju još u materici i ostaju nepromjenjeni tokom cijelog života. Ova vrsta analize potvrdila je jake veze između dermatglifskih karakteristika i pojedinih motoričkih sposobnosti, a uz to je i vrlo jeftina i visoko efikasna (Abramova, Nikitina i Ozolin, 1996; Junior, Cunha, Scheneider i Dantas, 2006; Kücken i Newell, 2005; Zary i Fernandes-Filho, 2007; Zary i saradnici, 2010).

Nepromjenljivost otisaka prstiju omogućava analizu njihove konfiguracije od djetinjstva, tako da je to korisno sredstvo za identifikovanje i obuku talentovanih pojedinaca na svim nivoima ljudskog razvoja, od početničkog do vrhunskog sportskog nivoa (Bogle, Reed i Norton, 1994; Cummins i Midlo, 1961; Linhares i saradnici, 2009). 
Uspješan nastup u pojedinim sportovima zahtijeva dobru anaerobni mišićnu moć (AMP). Ova motorička sposobnost je u vezi sa $\dot{\alpha}$-aktin izomorfom (ACTN3), koji je karakterističan za II tip brzo kontraktilnih mišićnih vlakana.ACTN3 je aktin-vezujući protein koji je dio Z linije sarkoma; on pomaže u organizovanju i održavanju kontraktilnog aparata i uređenju miofibrila (Macêdo i Fernandes-Filho, 2003; Mills i saradnici, 2001; North i saradnici, 1999; Holdys, Kryściak, Stanisławski, \& Gronek, 2011; Papadimitriou, Papadopoulos, Kouvatsi, \& Triantaphyllidis, 2008).

577R alela ACTN3 gena proizvodi aktivni ACTN3 protein u RR homozigotu i RX heterozigotu. Ti genotipovi su pogodni za anaerobne aktivnosti i nalaze se kod vrhunskih sportista i olimpijaca sprintera. ACTN3 R577X polimorfizam takođe može da se identifikuje u djetinjstvu i određivanje genotipa za ovaj lokus može dati informacije o genetskim predispozicijama pojedinca za AMP (Druzhevskaya, Ahmetov, Astratenkova i Rogozkin, 2008; Eynon i saradnici, 2009; Moran i saradnici, 2007; Yang i saradnici, 2003).

Priustvo aktivnog ACTN3 nije od vitalnog značaja za organizam pošto $\dot{\alpha}$-aktin izoform 2 (ACTN2) na zadovoljavajući način može da nadoknadi njegov nedostatak u normalnom svakodnvenom funkcionisanju. Međutim, odsustvo ACTN3 čini se da spriječava sportske mišićne sposobnosti tipa anaerobne mišićne moći, a pojedinci sa XX genotipom se u suštini i ne nalaze među onim vrhunskim sportistima koji se takmiče u onim aktivnostima koje zahtijevaju visok nivo ovih fizičkih predispozicija (Bustamante-Ara i saradnici, 2010; Norman i saradnici, 2009; Roth i saradnici, 2008; Scott i saradnici, 2009).

Pošto je utvrđen dermatoglifski profil i polimorfizam ACNT3-ov R577X, cilj ovog istraživanja bio je da se ustanovi procenat ljudi koji žive u saveznoj brazilskoj državi Paraiba a koji koji ne bi bili dobri kandidati za sportove koji zahtijevaju AMP.

\section{METODE}

\section{Provođenje istraživanja i ispitanici}

Uzorak ovog istraživanja nasumično je odobaran među učenicima starosti 7-17 godina koji žive u saveznoj brazilskoj državi Paraiba. Deskrištivni profil urađen je pomoću eks post fakto tipologije koja je prepoznala karakteristike otisaka prstiju 309 ispitanika (149 dječaka i 160 djevojčica), a među nima 96 ispitanika (40 dječaka i 56 djevojčica) su genetipizirani na ACTN3.

Digitalni otisci (DIs) i ćelije iz sluzokože usne šupljine su prikupljeni u UNIPÊ/SANNY laborato- riji Univerziteta João Pessoa - UNIPÊ od strane jednog istraživača (C.R.P.). Prikupljani biološki materijal potom je prenjet u laboratrorijski kompleks Policijskog instituta države Paraiba (SPI/PB).

Istraživanje je odobreno od strane Etičkog komiteta za istraživanja na ljudima Lauro Wanderley univerzitetske klinike (EC/LWUH) na osnovu prtokola broj 677-10. Potpsani obrazci da se dobrovoljnom voljom pristaje na istraživanje dobijeni su od svih roditelja ili staratelja u skladu sa Helsinškom deklaracijom iz 1975. godine

\section{Protokol za prikupljanje dermatoglif- ska podataka i analiza}

DIs su prikupljeni $i$ analizirani kako su opisali Cummins i Midlo (1961). Forenzički razredi i valjani DIs su uzeti pomoću Cross Match ${ }^{\circledR}$ Verifier 320 LC skenera koji je bio povezan sa računarom. DIs su bili klasifikovani: bez delta Luk (A), jedna delta Kuka (L) i dve delete Spirala (W).

Potom je broj delti na deset prstiju (D10) na rukama identifikovan iz njihovog zbira. Ukupan zbir linija (STQL) dobijen je prebrojavanjem pronađenih delta šara i DI nukleusa na svim prstima, odbijajući od toga broja prvu i zadnju šaru.

Osobe koje se oznavačaju kao one koje nemaju predispozicije za AMP su one koje nemaju dermatoglifske karakteristike opisane od strane Abramova, Nikitina i Ozolin (1996): A=1 ili 2; L=7 ili 8; W=1 ili 2; STQL $\leq 134$; i $\mathrm{D} 10 \leq 13$.

\section{Protokol za prikupljanje ACTN3 genotipa i analiza podataka}

Biloški materijal, ACTN3 R577X polimorfizan za analizu uziman je od oralnih ćelija sluzokože koja se prikupljala uz pomoć sterilne vate pomoću koje je pravljen bris unutrašnje šupljine usta sve dok pamuk ne pokupi pljuvačku. Sakupljani materijal je podvrgnut očitavanju DNA kao što je to opisano od strane Walsh, Metzger i Higuchi (1991). Genotipovi su određivani uz pomoć reakcije lanca pliomeraze (PSTs) u realnom vremenu uz pomoć IQ5 Thermal Cycler (Biorad) PCR aparata kako bi se ustanovio R577X polimorfizam (analiza Id C5900931-Applied Biosystems).

\section{Statistička analiza}

Da bi se predstavili rezultati dermatoglifskih frekvencija A, L, W, D10 i STQL kao i frekvencija ACTN3 R577X polimorfizma gena utvrđenih prebrojavanjem korištena je deskriptivna statistika. Frekvencije su predstavljene kroz procentulane vrijednosti. Sve analize su provedene uz pomoć statističkog paketa za društvene nauke (SPSS), verzija 14.0. 


\section{REZULTATI}

\section{Dermatoglifski profili}

Od 309 ispitanih osoba, na osnovu njihovog dermatoglifskog profila, njih 291 (94,2\%) su klasifikovane kao pojedinci koji nemaju AMP predispozicije. Unutar ove grupe otkriveni su pojedinci sa visokom rezistentnošću na: brzinu (14,0\%), maksimalnu snagu (4,1\%), izdržljivost $(46,9 \%)$ i motornu koordinaciju (29,2\%). Samo 18 $(5,8 \%)$ ispitanika imalo je dermatoglifski profil koji je ukazivao na sklonosti za sportove koji traže veliku moć mišićne kontrakcije.

\section{ACTN3 genotipovanje}

Od 96 ispitanika za koje je ustanovljen ACTN3 genotip, 19,8\% su bile XX homozigotne, 47,9\% RX heterozigotne i 32,3\% RX homozigotne. Kako RR homozigotne kao i RX heterzigotne sadrže aktivnu formu ACTN3, 80,2\% ispitanika nije isključeno iz moogućnosti da potencijalno ima AMP predispozicije. 19,8\% ispitanika kod kojih je ustanovljen XX gentip klasikovani su kao oni koji vjerovatno nisu u stanju da izvedu kontrakcije sa visokim sposobnostima AMP.

\section{DISKUSIJA}

Ovo je pionirska vrsta istraživanja u kojoj je identifikovana relativna frekvencija pojedinaca koji nemaju predispozicije za izvođenje visoko moćnih mišićnih kontrakcija u populaciji osoba koja živi u saveznoj državi Paraiba (Brazil), a baziralo se na dermatoglifici i ACTN3 polimorfizmu genotipova.

Pristup dermatoglifskom klasifikacijom bio je u stranju da bolje identifikuje ljude koji nemaju predispozicije za APM (94,2\%) nego ACTN3 analiza (19,8\%). Ipak, treba napomenuti da je dermatoglifski pristup uključen u asocijativnu analizu (Abramova, Nikitina i Ozolin, 1996), dok su ispitanici sa postojanjem XX genotip identifikovani kao oni koji nisu u stranju da izvrše visoko snažne kontrakcije zbog nedostatka aktivnog ACTN3 proteina koji ima uticaj na funkcionalan način kontraktilnog aparata neophodnog za brzu kontrakciju (Roth i saradnici, 2008; Scott i saradnici, 2009).

\section{Dermatoglifika}

Dermatoglifska klasifikacija pojedinaca koji imaju predispozicije za AMP proizilazi iz kvalitativne i kvantitativne analize pokazatelja dobijenih iz DIs subjekata. U istraživanju dermatoglifskih karakteristika na 122 adolescenta oba pola, koji nisu bili spor- tisti i koji žive u gradu Resende - Rio de Žaneiro u Brazilu (Klein i Fernandes-Filho, 2003), utvrđeno je da oko 59,0\% subjekata ima dermatoglifske šare koje ne idu u prilog AMP-u. U sličnom itraživanju 96 ljudi koji žive u gradu Niterói - Rio de Žaneiro u Brazilu 2003. godine, koje je imalo sličan profil kao i kod subjekata u istraživanju Kleina i Fernandes-Filho's (2003), Macêdo i Fernandes-Filho (2003) su ustanovili da 76,0\% ispitanika nije posjedovalo predispozicije za AMP. Procenat ispitanika bez predispozicija za AMP, koji je ustanovljen u ovim prethodnim brazilskim istraživanjima (Klein i FernandesFilho, 2003; Macêdo i Fernandes-Filho, 2003), bio je niži nego što je pronađen u ovom istraživanju.

Dakle, rezultati dobijeni na uzorcima analiziranim u prethodne dvije brazilske studije u saveznoj državi Rio de Žaneiro (Klein i Fernandes-Filho, 2003; Macêdo i Fernandes-Filho, 2003) nisu jednaki ovim koji su ustanovljeni u Paraibu, a kada je u pitanju relativna učestalost pojave pojedinaca sa dermatoglifskim karakteristikama za AMP. Nalazi ovog istraživanja potvrđuju rezultate prethodnih istraživanja u smislu efikasnosti dermatoglifske metode kao instrumenta za procjenu i utvrdivanje populacionog profila sa predispozcijama za motoričke aktivnosti, s obzirom da postoji visoka povezanost između papilarnih šara i motoričkih kvaliteta i kod adolescenata i kod vrhunskih sportista (Junior i saradnici, 2006; Linhares i saradnici, 2009; Zary i Fernandes-Filho, 2007; Zary i saradnici, 2010).

\section{ACTN3 genotipovanje}

Diskusija o ACTN3 polimorfizmu je uglavnom usmjerena oko mutacije XX homozigotnih genotipova pošto ona diferencira potencijalne sportiste $u$ smislu njihove sposobnosti da stvaraju aktivni ACTN3 (Roth i saradnici, 2008; Ruiz i saradnici, 2010; Scott i saradnici, 2009).

Kako bi se izveli tekući zaključci iz dobijenih rezultata genotipa, procenat XX genotipa pojedinaca koji se odnosi na istraživanje provedeno na brazilskoj populaciji upoređeno je sa procentima dobijenim u ispitivanjima u drugim geografskim područjima (Tabela 1). Traba zapaziti da rezultati iz ovog istraživanja (19 od 96 osoba imalo je XX genotip na 577 lokusu ACTN3 protein gena) je po proporciji slično zaključcima do kojih su došli Ruiz i saradnici (2011) sa učenicima na časovima fizičkog vaspitanja, Norman i saradnici (2009) na ženama i muškarcima bjelcima, Eynon i saradnici (2009) na ispitanicima bjelcima, Papadimitriou i saradnici (2008) u svojoj kontrolnoj grupi i Yang i saradnici (2003) kod zdravih bijelaca djece i odraslih. Istraživanja koja su ustanovile blago niži 


\section{TABELA 1}

Poredenje frekvencija XX homozigotnog genotipa R577X polimorfizma ACTN3 proteima po zemljama.

\begin{tabular}{llc}
\hline \multicolumn{1}{c}{ Istraživanje } & \multicolumn{1}{c}{ Zemlja } & XX frekvencija (\%) \\
\hline Paz i saradnici, 2012 & Brazil & 19,8 \\
\hline Zempo i saradnici, 2010 & Japan & 24,8 \\
\hline Norman i saradnici, 2009 & Švedska & 19,0 \\
\hline Papadimitriou i saradnici, 2008 & Grčka & 18,2 \\
\hline Ruiz i saradnici, 2011 & Španija & 18,3 \\
\hline Yang i saradnici, 2003 & Australija & 18,0 \\
\hline Eynon i saradnici, 2009 & Izrael & 18,0 \\
\hline McCauley, Mastana i Folland, 2010 & Velika Britanija & 16,0 \\
\hline Druzhevskaya i saradnici, 2008 & Rusija & 14,2 \\
\hline Niemi, 2005 & Finska & 9,2 \\
\hline Scott i saradnici, 2009 & Jamajika & 2,0 \\
\hline Scott i saradnici, 2009 & Sjedinjene Države & 4,0 \\
\hline
\end{tabular}

odnos XX genotipova pojedinaca takođe su prijavljenaod McCauleya, Mastana i Follanda (2010) kod muškaraca između 60 i 70 godina starosti, Druzhevskaya i saradnika kod muškaraca i žena bijelaca i Niemia i Majamaa (2005) kod njihove kontrolne grupe. Znatno niži odnos XX genotipa pojedinaca ustnovili su Scott i saradnici (2009) za grupe jamaičana i stanovnika SAD afričkog porijekla. Samo uzorak žena u postmenopauzi u Japanu u istraživanju Zempoa i saradnika (2010) pokazao je učestalost XX genotipova $(24,8 \%)$ koji je bilo veći nego što je nađen u ovom istraživanju.

Dakle, u vezi sa relativnom frekvencijom mutiranog XX homozigotnog polimorfizma, ovim istraživanjem dobili smo frkevenciju sličnu onoj koju su dobile stidije provedene u različitim dijelovima svijeta (uključujući Švedsku, Grčku, Australiju, Španiju i Izrael) (Eynon i saradnici, 2009; Norman i saradnici, 2009; Papadimitriou i saradnici, 2008; Ruiz i saradnici, 2011; Yang i saradnici, 2003) što ukazuje da se učestalost XX genetske konfiguracije ne razlikuje u velikoj mjeri u svjetskoj populaciji.

U pogledu alela kodiranja aktivne forme ACTN3, frekvencija RR i RX genotipova i u ovoj studiji su slične onima iz nekoliko drugih, posebno u istraživanjima sa više RX heterozigotnih nego RR homozigotnih, uključujući Ruiza i saradnike (2011) RR 31,1\% i RX $50,6 \%$, Zempa i saradnike (2010) RR 17,4\% i RX $57,8 \%$, Normana i saradnike RR $31,0 \%$ i RX 50,0\%, Eynona i saradnike (2009) RR 20,0\%, Neimuena i Majamaa (2005) RR 45,0\% i RX 45,8\%, Yanga i saradnike (2003) RR 30,0\% i RX 52,0\%, Druzhevckaya i saradnici (2008) RR 36,8\% i RX 49,0\% i Papadimitriou i saradnici (2008) RR 25,9\% i RX 55,8\%. Na drugoj strani kod McCauleya, Mastana i Follanda (2010) RR 43,0\% i RX 41,0\% i Scotta i saradnika (2009) u kontrolnoj grupi jamaičana RR 75,0\% i RX $23,0 \%$ i stanovništva SAD afričkog porijekla RR 66,0\% i RX 30,0\% primjetno je veći procenat RR homozigotnog genotipa.

ACTN3 gen postao je važan molekularni marker za predviđanje vrhunskog sportskog postignuća zbog povezanosti R577 alele sa eltinim sprinterima (Druzhevskaya i saradnici, 2008; Eynon i saradnici, 2009; Moran i saradnici, 2007; Papadimitriou i saradnici, 2008; Yang i saradnici, 2003). Istovremeno, različita istraživanja pokazala su da se mutirani XX homozigotni genotip rjeđe nalazi kod sportista i da to može uticati na izvođenje mišićne kontrakcije koja se traži kod AMP (Berman i North, 2010; Roth i saradnici, 2008; Scott i saradnici, 2009).

Ove pretpostavke pokazuju jasnu važnost identifikacije i odbacivanja pojedinaca koji su homozigotni za ACTN3 577X alele kao način selekcije pojedinaca za sportove koji zahtijevaju AMP, pošto se ova genetska konfiguracija (koja je prisutna kod 18\% svjetske populacije) obično nalazi kod vrhunskih sprintera. Ipak, Scott i saradnici su primjetili da 2 od 46 sportista koji su osvojili medalje na značajnim međunarodnim takmičenjima u brzini ili koji su obarali svjetske rekorde je imala XX genotip. Ovaj fenomen se može objasniti visokim nivoom ACTN2 nadoknade. Uprkos ovim izuzetcima XX genotip se može smatrati kao genetsko ograničenje koje ometa postizanje uspjeha u sportovima koji traže AMP.

Alela 577X može, pak, uvećati šanse sportista u sportovima tipa izdržljivosti (Berman i North, 2010; Eynon i saradnici, 2009; Papadimitriou i saradnici, 
2008; Scott i saradnici, 2009), iako Moran i saradnici nisu našli nikakve dokaze da je ova alela povezana sa izdržljivošću.

Istraživanje provedeno od strane Ruiza i saradnika (2010) analiziralio je ACTN3 R577X polkimorfizam i pet drugih polimorfizama (ACE I/D, AGT Met235Thr, GDF-8 K153R, IL6_174 G/C i NOS3_786T_C) u vezi sa dobrim rezultatima u izdržljivosti na uzorku sportista snage i brzine i kontrolne grupe u kojoj su svi bili sa Kavkaza. Oni su ustanovili da višegenetski profil samo djelomično razlikuje sportise snage od sportista izdržljivosti i kontrolne grupe. Njihovi rezultati pokazuju da, čak i djelimično, postoji genetska varijacija koja može napraviti razliku i voditi boljem odabiru koji sport odgovara kojem sportisti koji ima predispozicije da bude dobar u njemu.

\section{ZAKLJUČAK}

I dermatoglifska i metoda ACTN3 genotipiranja korišćene u ovom istraživanju pokazale su se kao efikasne za identifikaciju osoba koje nisu idelane za bavljenje AMP sportovima. Dermatoglifika je identifikovala mnogo veću grupu osoba koje ne posjeduju predispozicije za sportove koji traže AMP koji je u vezi od ACTN3 polimorfizmom genotipa. Ovi rezultati predstavljaju značajno smanjenje greške u traženju i izboru sportista sa potecijalom za vrhunska sportska dostignuća, posebno u sportovima koji zahtijevaju AMP. Bilo bi idealno kada bi kombinacija genetskih markera, koji su vezani za motoričke vještine, bila uključena u razvoj potencijalnih sportskih profila.

\section{IZJAVA ZAHVALNOSTI}

Želimo izraziti našu iskrenu zahvalnost dr Antônio Albuquerque Toscano i Forenzičkom DNA laboratoriju Naučno policijskog instituta SPI/PB za obavljenu DNA analizu.

\section{LITERTURA}

Abramova, T. F., Nikitina, T. M., \& Ozolin, N. N. (1996). Dermatoglyphic prints. genetic markers in the potential energy of man. Moscow Scientific Annals, 3(13).

Berman, Y., \& North, K. N. (2010). A gene for speed: The emerging role of $\alpha$-actinin- 3 in muscle metabolism. Physiology, 25, 250-259. doi: 10.1152/physiol.00008.2010; PMid: 20699471

Bogle, A. C., Reed, T., \& Norton, J. A. (1994). Within-pair differences in a-b ridge count asymmetry in monozygotic twins: evidence for a placental proximity effect. Hum Hered, 44, 162 168. doi: 10.1159/000154209; PMid: 8039800

Bustamante-Ara, N., Santiago, C., Verde, Z., Yvert, T., Gómez-Gallego, F., Rodríguez-Romo, G., ... Lucia A. (2010). ACE and ACTN3 genes and muscle phenotypes in nonagenarians. Int J Sports Med, 31, 221-224. doi: 10.1055/s-00301247529; PMid: 20148371

Cummins, H., \& Midlo, C. H. (1961). Fingerprints, palms and soles: an introduction to dermatoglyphics. New York: Dover Publications Inc.

Druzhevskaya, A. M., Ahmetov, I. I., Astratenkova, I. V., \& Rogozkin, V. A. (2008). Association of the ACTN3 R577X polymorphism with power athlete status in Russians. Eur J Appl Physiol, 103, 631-634. doi: 10.1007/s00421-008-0763-1; PMid: 18470530

Eynon, N., Duarte, J. A., Oliveira, J., Sagiv, M., Yamin, C., Meckel, ... Goldhammer, E. (2009). ACTN3 R577X Polymorphism and Israeli Toplevel Athletes. Int J Sports Med, 30, 695-698. doi: 10.1055/s-0029-1220731; PMid: 19544227

Holdys, J., Kryściak, J., Stanisławski, D., \& Gronek, P. (2011). Polymorphism of the $\alpha$-actn 3 gene in individuals practising different sports disciplines. Biol Sport, 28, 101-106. doi: 10.5604/942738

Junior, A. T. C., Cunha, A. C. P. T., Scheneider, A. T., \& Dantas, P. M. S. (2006). Características dermatoglíficas, somatotípicas, psicológicas e fisiológicas da seleção brasileira feminina adulta de handebol [Features dermatoglyphics, somatotype, psychological and physiological of the Brazilian adult female handball]. Fit Perf J., 5, 81-86. doi: 10.3900/fpj.5.2.81.p

Kansal, D. K. (2010). A critical study of sports talent selection and promotion of sports participation, at young age. BrJ Sports Med, 44, i65-i66. doi: 10.1136/bjsm.2010.078725.219

Klein, C. M. O., \& Fernandes-Filho, J. (2003). Relação entre a dermatoglifia, as qualidades físicas e o nível maturacional de escolares adolescentes de ambos os sexos. Fit Perf J, 2, 321-329.

Kücken, M., \& Newell A. C. (2005). Fingerprint formation. J Theor Biol, 235, 71-83. doi: 10.1016/j.jtbi.2004.12.020; PMid: 15833314

Linhares, R. V., Matta, M. O., Lima, J. R. P., Dantas, P. M. S., Costa, M. B., Fernandes Filho, J. (2009). Efeitos da maturação sexual na composição corporal, nos dermatóglifos, no somatótipo e nas qualidades físicas básicas de adolescentes [Efeitos da maturação sexual na composição 
corporal, nos dermatóglifos, no somatótipo e nas qualidades físicas básicas de adolescentes]. Arq Bras Endocrinol Metab, 53, 47-54. doi: 10.1590/S0004-27302009000100008; PMid: 19347185

Macêdo, M. M., \& Fernandes-Filho, J. (2003). Estudo das características dermatoglíficas, somatotípicas e das qualidades físicas básicas nos diversos estágios de maturação sexual [Study of dermatoglyphic characteristics, somatotype and basic physical qualities in different stages of sexual maturation]. Fit Perf J, 2, 315-320. doi: 10.3900/fpj.2.6.315.s; doi: 10.3900/fpj.2.6.315.p

McCauley, T., Mastana, S. S., \& Folland, J. P. (2010). ACE I/D and ACTN3 R/X polymorphisms and muscle function and muscularity of older Caucasian men. Eur J Appl Physiol, 109, 269_ 277. doi: 10.1007/s00421-009-1340-y; PMid: 20069311

Mills, M. A., Yang, N., Weinberger, R. P., Vander Woude, D. L., Beggs, A. H., ... North, K. N. (2001). Differential expression of the actinbinding proteins, $\alpha$-actinin- 2 and -3 , in different species: implications for the evolution of functional redundancy. Hum Mol Genet, 10, 1335-1346. doi: 10.1093/hmg/10.13.1335; PMid: 11440986

Moran, C. N., Yang, N., Bailey, M. E. S., Tsiokanos, A., Jamurtas, A., MacArthur, D. G., ... Wilson, R. H. (2007). Association analysis of the ACTN3 R577X polymorphism and complex quantitative body composition and performance phenotypes in adolescent Greeks. Eur J Hum Genet, 15, 88-93. doi: 10.1038/sj.ejhg.5201724; PMid: 17033684

Niemi, A. K., \& Majamaa, K. (2005). Mitochondrial DNA and ACTN3 genotypes in Finnish elite endurance and sprint athletes. Eur J Hum Genet, 13, 965-969. doi: 10.1038/sj.ejhg.5201438; PMid: 15886711

Norman, B., Esbjörnsson, M., Rundqvist, H., Österlund, T., von Walden, F., \& Tesch, P. A. (2009). Strength, power, fiber types, and mRNA expression in trained men and women with different ACTN3 R577X genotypes. J Appl Physiol, 106, 959-965. doi: 10.1152/ japplphysiol.91435.2008; PMid: 19150855

North, K. N., Yang, N., Wattanasirichaigoon, D., Mills, M., Easteal, S., \& Beggs, A. H. (1999). A common nonsense mutation results in alphaactinin-3 deficiency in the general population. Nat Genet, 21, 353-354. doi: 10.1038/7675; PMid: 10192379
Papadimitriou, I. D., Papadopoulos, C., Kouvatsi, A., \& Triantaphyllidis, C. (2008). The ACTN3 gene in elite Greek track and field athletes. Int J Sports Med, 29, 352-355. doi: 10.1055/ s-2007965339; PMid: 17879893

Roth, S. M., Walsh, S., Liu, D., Metter, E. J., Ferrucci, L., \& Hurley, B. F. (2008). The ACTN3 $\mathrm{R} 577 \mathrm{X}$ nonsense allele is underrepresented in elite-level strength athletes. Eur J Hum Genet, 16, 391-394. doi: 10.1038/sj.ejhg.5201964; PMid: 18043716; PMCid: 2668151

Ruiz, J. R., Arteta, D., Buxens, A., Artieda, M., Gómez-Gallego, F., Santiago, C., ... Lucia, A. (2010). Can we identify a power-oriented polygenic profile? J Appl Physiol, 108, 561-566. doi: 10.1152/japplphysiol.01242.2009; PMid: 20044471

Ruiz, J. R., del Valle, M. F., Verde, Z., Díez-Veja, I., Santiago, C., Yvert, T., ... Lucia, A. (2011). ACTN3 R577X polymorphism does not influence explosive leg muscle power in elite volleyball players. Scand J Med Sci Sports, 21, e3441. doi: 10.1111/j.1600-0838.2010.01134.x; PMid:0561285

Scott, R. A., Irving, R., Irwin, 1., Morrison, E., Charlton, V., Austin, K., ... Pitsiladis, Y. P. (2009). ACTN3 and ACE genotypes in elite Jamaican and US sprinters. Med Sci Sports Exerc, 42, 107-112. doi: 10.1249/

MSS.0b013e3181ae2bc0; PMid: 20010124

Walsh, P. S., Metzger, D. A., \& Higuchi, R. (1991). Chelex 100 as a medium for simple extraction of DNA for PCR-based typing from forensic material. Biotechniques, 10, 506-513. PMid: 1867860

Yang, N., MacArthur, D. G., Gulbin, J. P., Hahn, A. G., Beggs, A. H., Easteal, S., \& North, K. (2003). ACTN3 genotype is associated with human elite athletic performance. Am J Hum Genet, 73, 627-631. doi: 10.1086/377590; PMid: 12879365; PMCid: 1180686

Zary, J. C. F., \& Fernandes-Filho, J. (2007). Identificação do Perfil Dermatoglífico e Somatotípico dos Atletas de voleibol masculino adulto, juvenil e infanto-juvenil, de alto rendimento no Brasil [Identification and Profile Dermatoglyphic somatotypical Athletes volleyball adult male, juvenile and juvenile, high yield in Brazil]. R bras Ci e Mov, 15, 53-60.

Zary, J. C., Reis, V. M., Rouboa, A., Silva, A. J., Fernandes, P. R., \& Fernandes Filho, J. (2010). The somatotype and dermatoglyphic profiles of adult, junior and juvenile male Brazilian top- 
level volleyball players. Sci Sports, 25, 146-152. doi: 10.1016/j.scispo.2009.09.002

Zempo, H., Tanabe, K., Murakami, H., Iemitsu, M., Maeda, S., \& Kuno, S. (2010).
ACTN3Polymorphism Affects Thigh Muscle Area. Int J Sports Med, 31, 138-142. doi: 10.1055/s-0029-1242808; PMid: 20222007

Primljeno: 26. februar 2013. godine Izmjene primljene: 11. jun 2013. godine Odobreno: 29. jun 2013. godine

Korespondencija: Carlos Renato Paz 182 Aderbal Piragibe av., Jaguaribe, João Pessoa city, State of Paraíba, Country: Brazil. ZIP CODE: 58015-000

Phone: 00558388500504 E-mail: renatopaz@hotmail.com 